\title{
Filter Pie in the Control of the Nematoid of Root Lesions in the Soybean and Corn
}

\author{
Rafaela Santos de Oliveira ${ }^{1}$, Anderli Divina Ferreira Rios ${ }^{2}$, Manoel Henrique Reis de Oliveira ${ }^{3}$, \\ Rafael Matias da Silva ${ }^{3}$, Matheus Vinicius Abadia Ventura ${ }^{4}$, Kenia Lorrany Trindade ${ }^{3}$, \\ Grasiele Teixeira da Silva ${ }^{1}$, Antônio Evami Cavalcante Sousa ${ }^{3}$, Leônidas Miclos Baliza ${ }^{5}$, \\ Estevam Matheus Costa $^{4}$, Millena Yorrana Oliveira Silva ${ }^{1} \&$ Patrícia Borges Francalino ${ }^{1}$ \\ ${ }^{1}$ School of Agronomy, Evangelical Faculty of Goianesia, Goianesia, Brazil \\ ${ }^{2}$ Postgraduate Program in Agronomy, Goias Federal University, Goiania, Brazil \\ ${ }^{3}$ Postgraduate Program in Irrigation in the Cerrado, Goiano Federal Institute, Ceres, Brazil \\ ${ }^{4}$ Postgraduate Program in Agrarian Sciences-Agronomy, Goiano Federal Institute, Rio Verde, Brazil \\ ${ }^{5}$ School of Agronomy, Goiano Federal Institute, Rio Verde, Brazil \\ Correspondence: Rafaela Santos de Oliveira, School of Agronomy, Evangelical Faculty of Goianesia, Goianesia, \\ Brazil. Tel: 55-629-8647-6915. E-mail: rafaela.oliveiraeng@outlook.com
}

Received: January 20, 2019

doi:10.5539/jas.v11n11p130
Accepted: May 23, $2019 \quad$ Online Published: July 31, 2019

URL: https://doi.org/10.5539/jas.v11n11p130

\begin{abstract}
The efficiency of waste from industrial processing has been increasingly studied in the control of phytonematoids, especially filter cake, coffee husks and sugar cane bagasse. The objective of this study was to evaluate the effect of organic residues through the use of filter cake to reduce the population density of Pratylenchus brachyurus (Tylenchida: Pratylenchidae). The first experiment was conducted in a greenhouse in the completely randomized design in the $2 \times 4$ factorial scheme (soybean genotypes vs. filter cake doses) with four replications using soybean genotypes AS 3810 IPRO and LG60163 IPRO and the second experiment was carried out under the same conditions, with maize AG 1051 with four doses of filter cake with 7 replications. In both experiments, the planting was carried out in an area located in the city of Goianésia, Goiás, Brazil. The results showed that the population density of Pratylenchus brachyurus in the maize crop to grow AG 1051 did not show statistically significant difference by applying the different doses of filter cake. In soybean genotypes AS 3810 IPRO and LG60163 IPRO were affected in ways contrary to phytonematoid infestation, in which AS 3810 IPRO showed a population increase according to the increase of the applied amounts of filter cake, whereas in the cultivar LG60163 IPRO there was a decrease for doses of 10 tonnes $/ \mathrm{ha}^{-1}$ and 30 tonnes $/ \mathrm{ha}^{-1}$, with an increase of only 20 tonnes $/ \mathrm{ha}^{-1}$.
\end{abstract}

Keywords: Pratylenchus brachyurus, Zea mays L., Glycine max L.

\section{Introduction}

Nematodes are among the most numerous multicellular animals in the world, and can be found in all places, from deserts, oceans and hot regions (Goulart, 2008). All plant species are parasitized by nematodes (phytonematoids), but due to their small size and due to the symptoms caused in plants, they are confused with those of mineral deficiency or of another origin, and may pass unnoticed by farmers (Freitas et al., 2001). However, plant parasitic nematodes cause losses of 125 billion dollars annually (Fragoso, 2018). Feeding on the cellular contents, these pathogens divert to their nutrition the elements destined to the nutrition of the plant and the damages also can come from the toxic action of substances introduced by them in the roots.

The genus Pratylenchus is the second most important group of phytonematoids in the world, being supplanted only by the genus Meloidogyne. In Brazil, the genus Pratylenchus is commonly called the nematodes of the root lesions (Goulart, 2008). The species, Pratylenchus brachyurus (Tylenchida: Pratylenchidae) is a polyphagous phytonematoid and is associated mainly with plants of the family Poaceae (grasses) such as sugar cane, corn, rice, sorghum and brachiaria. However, they also parasitize other plants such as cotton and soybean (Rios et al., 2016; Rack et al., 2013; Barbosa et al., 2013; Neves, 2013; Machado et al., 2012) and the control of P. brachyurus nematoide in soybean areas is complex (Silva et al., 2019). Soybean is a widely cultivated crop in several 
Brazilian regions and is of great economic importance for the country (Costa et al., 2019) and the Central West region, the largest grain producer in Brazil (CONAB, 2017), faced in the last few seasons the occurrence of high-density P. brachyurus in the soybean crop. Sharma (1996) had already reported this high occurrence (31,970 specimens per 10 grams of roots) in soybeans in the late 1990s in Ipameri, Goiás. At the time, a $41 \%$ reduction in grain yield in the area affected by the nematod.

The frequent symptoms of $P$. brachyurus in the roots are mainly the injuries resulting in the formation of lesions that destroy their tissues. Still, they make the plants small, with thin branches, due to the complete destruction of the roots and radicels. The aerial part of affected plants can present chlorosis or wilting during the dry season. Total defoliation can occur when the attack is severe (Goulart, 2008).

Several methods can be used to control P. brachyurus, such as rotation or succession with non-host crops, biological control, the use of resistant plants, chemical control, use of organic matter (organic waste) and the use of antagonistic plants (Ferraz et al., 2010). However, for P. brachyurus because it has polyphagus habit, there is a wide range of hosts and the use of rotation is difficult.

Maize is the main crop used in succession in soybean area, but this culture promotes an increase in the population density of $P$. brachyurus in the area, as it is highly susceptible to the nematode damaging the next soybean crop (Inomoto et al., 2011). Chemical control is ineffective and environmentally incorrect and the biological control is still incipient, few studies confirming its efficiency for the nematodes of the genus Pratylenchus at the field level. Genetic resistance is the best method, compatible with other management practices and does not harm the environment. However, obtaining broad resistance is difficult, time-consuming, and sometimes resistant plants do not have desirable agronomic characteristics (Freitas et al., 2001; Ritzinger \& Fancelli, 2006). For the nematode P. brachyurus, genetic resistance to soybean cultivation is not yet known.

There is a growing demand for sustainable methods for disease control in plants, and thus the addition of organic waste to soils, which is a very old practice and which improves the structure and fertility of soils, can be a good alternative to control of nematodes in agriculture. The amplitude of the nematicidal effect depends on the type and amount of the residue used or the host plant (Stirling et al., 2003). The main sources of organic residues used in the management of nematodes are animal waste, urban waste, seed tarts, plant biomass of antagonistic plants and agroindustrial residues (Ferraz et al., 2010).

Various wastes are generated during agro-industrial processing and the utilization of these by-products in agriculture may be an ecologically desirable option. The most studied agroindustrial residues in nematode control are seed tarts, coffee husks, sugarcane bagasse, manure, cellulosic waste and filter cake that is a residue of the sugar and alcohol industry (Ferraz et al., 2010). These residues are chosen according to their greater availability in the region where they will be used. Several investigators have reported the suppression of nematodes after the application of the filter cake. Meloidogyne incognita populations in maize, and M. javanica and P. brachyurus in cane, were suppressed by increasing doses of filter cake (Oliveira et al., 2005; Albuquerque et al., 2002).

Therefore, the present work aims to evaluate the effect of organic residues through the use of filter cake in reducing the population density of $P$. brachyurus in soybean and corn crop. These measures can be integrated into an integrated nematode management program in soybean and corn in an efficient, economically viable and environmentally sustainable way. This will be done through studies under controlled conditions of greenhouse with soil infested by the nematode.

\section{Method}

The first experiment was conducted in a protected environment with cover, in transparent polyethylene suitable for greenhouse and nurseries, with protected sides with screen. The structure was composed with dimensions of $1.5 \mathrm{~m} \times 3.0 \mathrm{~m}$ with right foot of 2.0 meters, with north-south orientation, located in the city of Goianésia, Goiás, Brazil. The experimental design was a completely randomized design with four replicates, in $2 \times 4$ (soybean genotypes vs. filter cake doses), totaling 8 treatments and 32 experimental units. Naturally infested soil was obtained from commercial property with a history of nematode reboleira. The soil was homogenized, for substrate composition in $2 \times 1$, soil and sand sterilized by autoclave and arranged in plastic pots with a capacity of 5 liters.

The planting was carried out on February 16, 2018, with the genotypes Monsanto AS 3810 IPRO and LG60163 IPRO, containing in each pot three liters of substrate (two liters of soil and one litter of sand), distributed ten seeds per pot. Planting fertilization was performed with the formula 06-30-10, after calculation of the recommendation for second soybean crop (Sousa \& Lobato, 2004). The inoculation of the nematodes was 
performed approximately 30 days after sowing, respectively on March 13, 2018 in the cultivar Monsanto AS 3810 and on March 17, 2018 with cultivar LG60163 IPRO, by the method of infested soil, adding 150 grams of soil per pot, the inoculum was conserved in corn plants with density of 500 individuals per gram of soil. The application of the filter cake was performed in the following (doses: 0;10;20; $30 \mathrm{t} \mathrm{ha}^{-1}$ ), on March 29, 2018 and April 9, 2018 according to the inoculation sequence.

At 30 days after sowing, thinning was done leaving four plants per pot. Cultural dealings were made according to the need of culture. Irrigation was conducted daily, and cover fertilization was carried out at the beginning of flowering, periodically performing the soil rotation to avoid surface compaction and fungal growth. The evaluation of the agronomic traits and the population density of the nematoid in the roots of soybean plants were carried out at 50 days after inoculation. The plants were collected, the roots and aerial part were separated, properly identified and conditioned in plastic bags and taken to the Phytotechnology and Phytopathology laboratories of the Evangelical Faculty of Goianésia for evaluations. For the aerial part, the agronomic characters, height of plants $(\mathrm{cm})$, green matter of the aerial part $(\mathrm{g})$, number of leaves were evaluated.

The second experiment was carried out with corn cultivar AG 1051, planting was carried out in April 2018, in a private property in the municipality of Goianésia, Goias in Brazil. The soil was homogenized for substrate composition in $2 \times 1$, soil and sand sterilized by autoclaving and placed in plastic pots with a capacity of 5 liters, the fertilization was performed after 8 days after sowing with the formulation 06-30-10 according to the culture requirement. They were distributed in a completely randomized design with $1 \times 4$ (cultivar vs doses of filter cake) with seven replicates.

The inoculation of the nematodes was carried out approximately 35 days after sowing, and on May 15, 2018, by the infested soil method, adding 150 grams of soil per pot, the inoculum was conserved in maize plants with a density of 500 individuals per gram of soil. The application of the filter cake was performed in the following (doses: $0 ; 10 ; 20 ; 30 \mathrm{tha}^{-1}$ ) on May 02, 2018. Root evaluation was performed 30 days after inoculation.

Root evaluation was performed with root length $(\mathrm{cm})$, root weight $(\mathrm{g})$ and nematode population densities. In the laboratory, the roots were processed according to methodology described by Coolen and D'Herde (1972). The roots were brought to the blender the total portion of the roots of each treatment, added $500 \mathrm{~mL}$ of water and crushed for thirty seconds. The obtained suspensions were poured into a sieve with 100 mesh apertures overlapped with a 400-mesh aperture. Residues retained in the 100-mesh sieve were discarded and the nematodes retained in the 400-mesh sieve were transferred to plastic containers with a lid. Identification and quantification of the phytonematoids from the experiment samples were performed with the aid of an optical microscope with the aid of a Peters chamber.

For analysis of the reading data, they were submitted to the Shapiro Wilk normality test, and the necessary transformations for each variable were applied, using transformations for $\log (\mathrm{x})$ and $\sqrt{\mathrm{x}}$. Using the software Sisvar 5.6 (Ferreira, 2014). And submitted to the test of average, Tuckey for qualitative sources of variation being the genotypes and the unfolding genotypes $\mathrm{x}$ doses and linear regression for sources of quantitative variation referring the doses of filter cake for the two cultures.

\section{Results}

The results obtained for the variables, plant height, shoot weight and density are expressed in Table 1, the evaluations carried out show that there were significant differences in all variables analyzed, with interaction between the doses and the genotypes. Reduction in plant height was observed according to the increase of filter cake doses, but should take into account the morphological characteristics of each cultivar. For the shoot weight, there was difference only in cultivar AS 3810 IPRO, and for population density that refers to the number of individuals per ten grams of root, differences were found between the doses and among the genotypes. 
Table 1. Dosage and cultivation, for the agronomic characteristics and population in the soybean crop, inoculated with infested soil. The variables are: plant height, air part weight, population density

\begin{tabular}{|c|c|c|c|c|c|c|}
\hline \multirow{2}{*}{ Filter Cake Doses (t/ha) } & \multicolumn{6}{|c|}{ Genotypes } \\
\hline & LG60163 & AS 3810 & LG60163 & AS 3810 & LG60163 & AS 3810 \\
\hline & \multicolumn{2}{|c|}{ Plant Height $(\mathrm{cm})$} & \multicolumn{2}{|c|}{ Air Part Weight* $(\mathrm{g})$} & \multicolumn{2}{|c|}{ Population Density** (individual/10 g root) } \\
\hline 0 & $60.65 \mathrm{Aab}$ & $51.32 \mathrm{Ba}$ & $3.77 \mathrm{Ba}$ & $5.85 \mathrm{Aa}$ & $261.82 \mathrm{Aab}$ & $222.17 \mathrm{Ab}$ \\
\hline 10 & $61.00 \mathrm{Aa}$ & $46.45 \mathrm{Bab}$ & $3.01 \mathrm{Ba}$ & $4.85 \mathrm{Aab}$ & $151.02 \mathrm{Bbc}$ & $470.94 \mathrm{Aa}$ \\
\hline 20 & $49.00 \mathrm{Abc}$ & $53.40 \mathrm{Aa}$ & $3.71 \mathrm{Aa}$ & $4.40 \mathrm{Ab}$ & $255.39 \mathrm{Ba}$ & $518.15 \mathrm{Aa}$ \\
\hline 30 & $45.85 \mathrm{Ac}$ & $38.78 \mathrm{Ab}$ & 4.08 Aa & $3.77 \mathrm{Ab}$ & $126.27 \mathrm{Bc}$ & $296.92 \mathrm{Ab}$ \\
\hline $\operatorname{LSD}(0.05)$ & 11.80 & & 17.51 & & 5.76 & \\
\hline
\end{tabular}

Note. Values followed by equal lowercase letters in the column and values followed by equal capital letters in the row do not differ statistically by the Tukey test at $5 \%$. $*$ Data transformed by $\sqrt{\mathrm{x}}$ and $* *$ Data transformed by $\log (\mathrm{x})$.

The variables in analysis did not obtain interaction between doses and cultivar, being shown in Table 2 and Chart 1 the independent variables, being: leaf number and fresh root weight and in graph 1 was performed the regression from a linear equation with $\mathrm{R}^{2}$.

Table 2. Number of leaves and Fresh root weight in genotypes AS 3810 IPRO and LG60163 IPRO inoculated with soil infested with $P$. brachyurus

\begin{tabular}{lll}
\hline Cultivares & Number of leaves* & Fresh root weight** $(\mathrm{g})$ \\
\hline LG60163 IPRO & $3.24 \mathrm{~b}$ & $0.91 \mathrm{~b}$ \\
AS 3810 IPRO & $4.30 \mathrm{a}$ & $1.05 \mathrm{a}$ \\
\hline LSD $(0.05)$ & 29.13 & 16.81 \\
\hline
\end{tabular}

Note. Values followed by equal letters in the column do not differ statistically by the Tukey test at $5 \%$. * Transformation by $\sqrt{\mathrm{x}}$; ** Transformation by $\log (\mathrm{x})$.

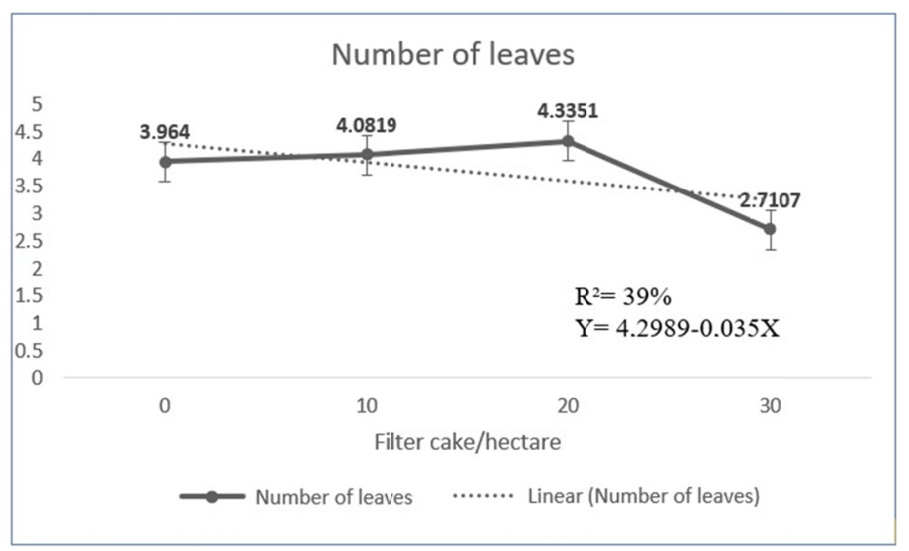

Graph 1. Regression number of leaves as a function of the filter cake doses 


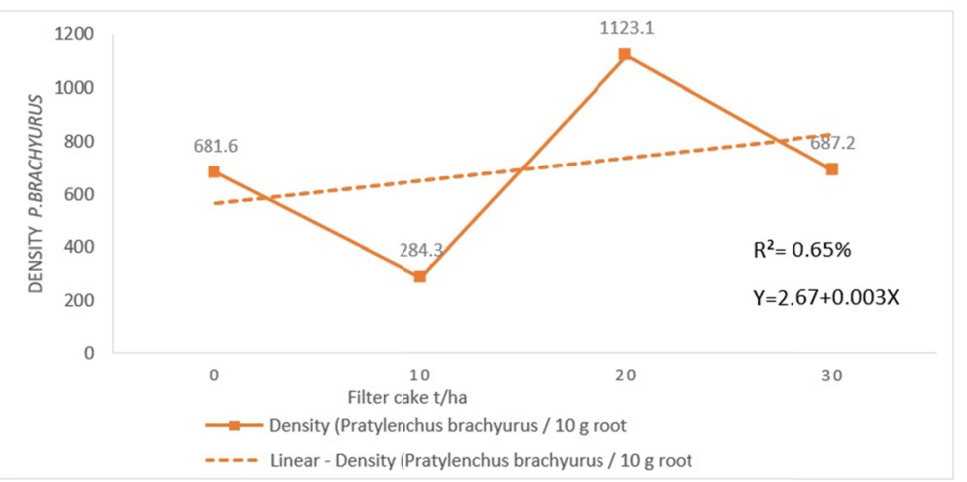

Graph 2. Density of Pratylenchus brachyurus on corn root cultivar AG 1051

\section{Discussion}

We can observe the interference of $P$. brachyurus in the evaluated traits, according to studies carried out we can report that according to Table 1 the genotypes ehaved like host for the nematode, but demonstrated their particularities in levels of tolerance to the nematoid of root lesions. The genotypes underwent reactions due to their availability to $P$. brachyurus.

As described by the work of Ferraz et al. (2010), several sources of organic matter have been used for the control of phytonematoids, such as animal waste and agroindustrial residues, but for some characteristics such as plant height the effects of the amount of the deposited matter influenced, so we can verify that the sources of organic matter influence the development of soybean plants infected by the phytonematoid P. brachyurus.

The density expressed in Table 1 showed the different behavior of the phytonematoids in relation to the doses and the cultivar, whereas, there was a reduction in the density according to the doses of filter cake for cultivar $\mathrm{L}$ 60163 IPRO, an increase occurred in the density according to with the increment of the filter cake to cultivate MS3810, thus demonstrating a better host for P. brachyurus. This confirms in parts with the studies done by (OKA, 2010) on the nematicidal action, increased tolerance and resistance of the plants when dealing with sources of organic matter due to the release of compounds during the degradation. In parts, the cultivar factor assigns a significant variation to the data shown.

The data on the weight of the aerial part of the two genotypes can be seen in contradiction with the study presented by Schmitt (2015), which describes that organic fertilizers based on cattle manure, straw and agroindustrial residues reduced the penetration of $P$. brachyurus into roots and increase the dry matter yield of the aerial part of the soybean plants when applied to the soil in the solid form. According to the results of this experiment for some genotypes the penetration of $P$. brachyurus in soybean roots can be reduced, but in relation to the mass of the aerial part in the two genotypes under study, there was reduction of the weight of the aerial part according to the doses of filter cake with exception only for the dose of 30 tonnes / ha in cultivar LG60163 IPRO, which had the increase of air part weight in relation to the other treatments.

The variations between the genotypes for leaf number and fresh root weight parameters were significant for the independent cultivar factor, as observed in Table 2, however due to the genetic characteristics of each cultivar we can have differentiations by the lodging of phytonematoids and by their genetics.

In Graph 1 we observed the interaction of the increase of the number of leaves in relation to the increase of the doses of filter cake, which may result in an increase of the photosynthetic rate and consequently increase of productivity, further studies become necessary for the evaluation of the physiological parameters of the culture when infected with this phytonematoid. The graph expresses that when the increase of the dose occurs, to the maximum 30 tons $/ \mathrm{ha}^{-1}$, a decrease in the number of leaves can express the point of negative influence for this characteristic.

All genotypes harbor nematodes. However, the filter cake improved the agronomic characteristics of the evaluated plants, but did not reduce the population density of nematodes. Few studies related to the use of alternative methods for the control of nematodes mainly with residues from agroindustrial processing such as filter cake are performed. Therefore, new studies are needed using alternative methods to control this nematode. 


\section{References}

Albuquerque, P. H. S., Pedrosa, E. M. R., \& Moura, R. M. (2002). Relações nematoide-hospedeiro em solo infestado por Meloidogyne spp. e tratado com torta de filtro e vinhaça. Nematologia Brasileira, 26(1), 27-34.

Barbosa, B. F. F., Santos, J. M., Barbosa, J. C., Soares, P. L. M., Ruas, A. R., \& Carvalho, R. B. (2013). Aggressiveness of Pratylenchus brachyurus to sugarcane, compared with key nematode P. zeae. Nematropica, 43(1), 119-130.

CONAB (Companhia Nacional de Abastecimento). (2017). Acompanhamento da Safra Brasileira de Grãos 2013/2014-Quinto Levantamento-março/2017.

Coolen, W. A., \& D'herde, C. J. (1972). A method for the quantitative extraction of nematodes from plant tissue (p. 77). Ghent, Belgian: State of Nematology and Entomology Research Station.

Costa, E. M., Nunes, B. M., Ventura, M. V. A., Mortate, R. K., Vilarinho, M. S., Silva, R. M., ... Bessa, M. M. (2019). Physiological Effects of Insecticides and Fungicide, Applied in the Treatment of Seeds, on the Germination and Vigor of Soybean Seeds. Journal of Agricultural Science, 11(4), 318-324. https://doi.org/ $10.5539 /$ jas.v11n 4 p318

Dias-Arieira, C. R., Ferraz, S., \& Ribeiro, R. C. F. (2009). Reação de gramíneas forrageiras a Pratylenchus brachyurus. Nematologia Brasileira, 33(1), 90-93.

Ferreira, D. F. (2014). Sisvar: A Guide for Its Bootstrap Procedures in Multiple Comparisons. Ciência e Agrotecnologia, 38(2), 109-112. https://doi.org/10.1590/S1413-70542014000200001

Ferraz, S., Freitas, L. G., Lopes, E. A., \& Dias-Arieira, C. R. (2010). Manejo sustentável de fitonematoides (pp. 71-84). Viçosa, MG.

Fragoso, R. R. (2018). Nova arma biotecnológica contra nematóides parasitas de plantas. Retrieved from http://www.cenargen.embrapa.br/cenargenda/pdf/criareplantar2502.pdf

Freitas, L. G., Oliveira, R. D. L., \& erraz, S. (2001). Introdução à Nematologia (p. 84). Viçosa: Universidade Federal de Viçosa.

Goulart, A. M. C. (2008). Aspectos gerais sobre nematoides das lesões radiculares (gênero Pratylenchus) (p. 30). Planaltina, DF: Embrapa Cerrados.

Inomoto, M. M., Siqueira, K., \& Machado, A. C. (2011). Crop rotation in center-pivot for phytonematode control: Density variation, pathogenicity and crop loss estimation. Tropical Plant Pathology, 36(3), 178-185.

Machado, A. C. Z., Ferraz, L. C. C. B., \& Inomoto, M. M. (2012). Pathogenicity of Pratylenchus brachyurus on cotton plants. Journal of Cotton Science, 16(4), 268-271.

Neves, D. L. (2013). Reprodução de Pratylenchus brachyurus em diferentes gramíneas forrageiras. Global Science and Tecnology, 6(1), 134-140. https://doi.org/10.14688/1984-3801.v06n01a12

Oka, Y. (2010). Mechanisms of nematode suppression by organic soil amendments-A review. Applied Soil Ecology, 44(2), 101-115. https://doi.org/10.1016/j.apsoil.2009.11.003

Oliveira, F. S., Rocha, M. R., Reis, A. J. S., Machado, V. O. F., \& Soares, R. A. B. (2005). Efeito de produtos químicos e naturais sobre a população de nematóide Pratylenchus brachyurus na cultura da cana- deaçúcar. Pesquisa Agropecuária Tropical, 35(3), 171-177.

Rack, V. M., Vigolo, F., Silva, R. A., Filho, G. A. G., \& Santos, P. S. (2013). Reação de cultivares de arroz de terras altas a dois isolados de Pratylenchus brachyurus. Nematologia Brasileira, 37(3-4), 37-41.

Rios, A. D. F., Rocha, M. R., Machado, A. S., Ávila, K. A. G. B., Teixeira, R. A., Santos, L. C., \& Rabelo, L. R. S. (2016). Host suitability of soybean and corn genotypes to the root lesion caused by nematode under natural infestation conditions. Ciência Rural, 46(4), 580-584. https://doi.org/10.1590/0103-8478cr 20150307

Ritzinger, C. H. S. P., \& Fancelli, M. (2006). Manejo Integrado de nematoides na cultura da bananeira. Revista Brasileira de Fruticultura, 28(2), 331-338. https://doi.org/10.1590/S0100-29452006000200041

Schmitt, J. (2015). Fertilizantes orgânicos na ação de Pratylenchus brachyurus em soja (Masters dissertation, Universidade Federal de Santa Maria).

Sharma, R. D. (1996). Nematoide de pastagem, Pratylenchus brachyurus atacando soja nos cerrados do Brasil Central. XXIX Congresso Brasileiro de Fitopatologia, Resumos... Brasília, DF, SBF. 
Silva, R. M., Rios, A. D. F., Conceição, D. R., Buso, W. H. D., Machado, A. S., Silva, G. T., ... Costa, E. M. (2019). Host Suitability of Weeds to the Root Lesions Nematoid in Soybean Areas in the North of Goias, Brazil. Journal of Agricultural Science, 11(4), 485-492. https://doi.org/10.5539/jas.v11n4p485

Stirling, G. R., Wilson, E. J., Stirling, A. M., Pankhurst, C. E., Moody, P. W., \& Bell, M. J. (2003). Organic amendments enhance biological suppression of plantparasitic nematodes in sugarcarne soils. Proceedings of the Australian Society of Sugar Cane Technologists, 25, 1-14.

\section{Copyrights}

Copyright for this article is retained by the author(s), with first publication rights granted to the journal.

This is an open-access article distributed under the terms and conditions of the Creative Commons Attribution license (http://creativecommons.org/licenses/by/4.0/). 